\title{
A DISCRETE EVENT SIMULATION OF A MUNICIPAL STREET TREE MAINTENANCE OPERATION
}

\author{
by James J. McCabe
}

\begin{abstract}
By using commercially available simulation software, a computer model for a typical municipal street tree maintenance operation is presented. Variables, such as the incoming work orders, crew assignments and productivity standards that represent the workflow of a service-on-demand street tree maintenance program, were included. Although additional simulated complexities are involved, the developed model provides a foundation from which managerial decision making and a typical tree care operation may be analyzed.

Key Words. Service-on-demand; municipal street tree maintenance; computer simulation.
\end{abstract}

Computer simulation has been used in many different disciplines as a means to gain greater insight into increasingly complex operation interactions (Diamond et al. 2000). Sophisticated software programs have become readily available and increasingly userfriendly to the point where the managers of private tree care firms and municipal arborists can incorporate this technology into their planning programs.

The intent of this paper was to develop a working computer simulation model of a municipal street tree maintenance operation using an inexpensive, off-the-shelf software program and then run the model to examine possible real-world application.

\section{MODEL DEVELOPMENT}

The simulation software package selected for this project was the Extend LT ver. 5.0.2, with accompanying Manufacturing and BPR modules, from Imagine That, Inc. This software was relatively inexpensive and provided graphic capabilities using illustrative icons. While the full version upgrade allows for virtually unlimited expansion potential, the project stayed with the limited 5.0.2 version due to ease of application by practitioners.

Although there is no such distinction in the real world, computer simulation models can be classified as continuous or discrete (Diamond et al. 2000). The developed computer model described in this paper is classified as a discrete event simulation because it represents a workflow over time by tracing work orders throughout the system. Law and Kelton (1991) describe a discrete system as "one for which the state variables change instantaneously at separated points in time." Law goes on to suggest that "these points in time are the ones at which an event occurs" (Law and Kelton 1991). The events that initiate and sustain this simulation are the resident service requests that result in work orders for municipal attention. The work order origination utilized in this model is based on a forecasted demand for municipal tree service on Staten Island, New York, U.S. (McCabe 2001). Figure 1 shows the frequency histogram of predicted forestry work orders that enter the system during each month of the year. Anticipated service requests are generated into the model each simulated day during a 250-day year, thereby disregarding all weekends and holidays.

Flowcharts (Figures 2, 3, 4, 5, and 6) represent the simulation model as follows:

1. A service request is received in the office and a work order is sent to the garage (Figure 2) from where a crew travels to perform pruning or removals.

2. The forester evaluates service requests (Figure 3) according to tree health conditions (dead, poor, fair, or good). The dead trees and those in poor health are designated for removal, while trees in fair or good condition are recommended for pruning. Due to the limitations of the LT version software, this model disregarded any complexities of the inspection process and instead allocated the work orders according to a percentage distribution of $33 \%$ removal and $67 \%$ pruning.

3. A crew is assigned the daily work in the garage (Figure 4). The pruning and removal work orders enter at connector A and are held in a buffer until they comprise a full day's work assignment. The daily workload is decided in the diamond labeled "distribute work." Workers generated into the system are batched into a crew at the "organize 
crew" diamond. When the crew departs the garage with their assignment, a time clock marks the time of the departure. After the assigned work is finished, the crew returns to the garage at connector $\mathrm{D}$ and separates itself from the completed work orders. The program marks the time of return as the crew exits.

4. Simulated tree removals are represented in Figure 5 and the simulated pruning work in Figure 6. The model identifies the time a crew arrives and departs a work site. Depending on the assigned workload the crew will proceed to one or more of several choices. For example, if two removals are assigned to the crew, they will advance to the diamond labeled "distribution" and get routed to two specific size class stations based on predetermined percentage probabilities. Once routed to the size class work station, the crew is delayed, allowing for the program to simulate the time involved in performing assigned work.

The time delay utilized in each size class work station was guided by studies conducted in Milwaukee, Wisconsin, and Toledo, Ohio. These two communities have documented tree-work-related productivity timing and performance standards. The Milwaukee program is referenced for their pruning productivity timing system (Zillmer et al. 2000), and the Toledo study is referenced for tree trimming and tree/stump removal work performance standards (O'Brien et al. 1992). This simulation project

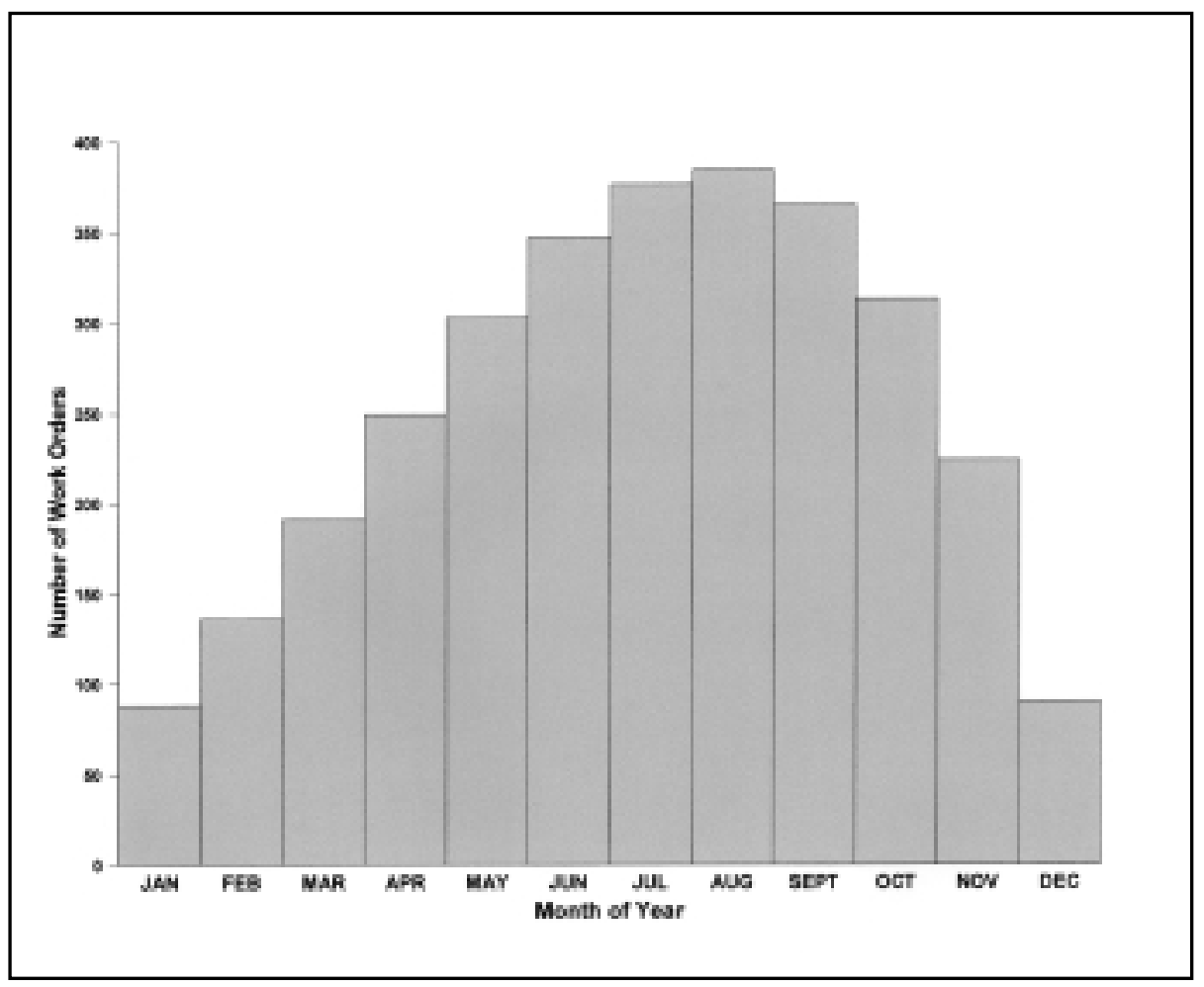

Figure 1. Annual frequency of work orders used in the model.

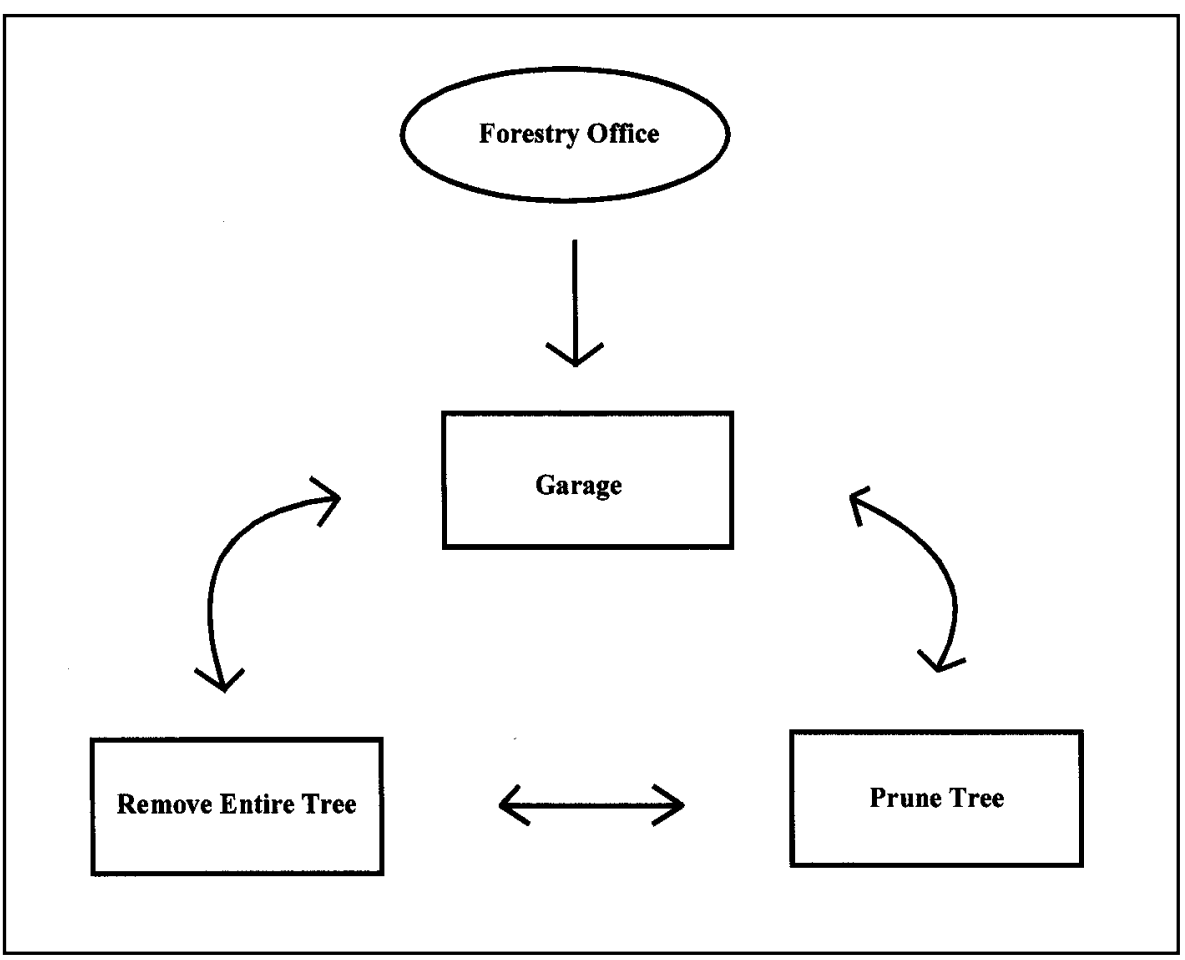

Figure 2. Overall flow of the simulation. 


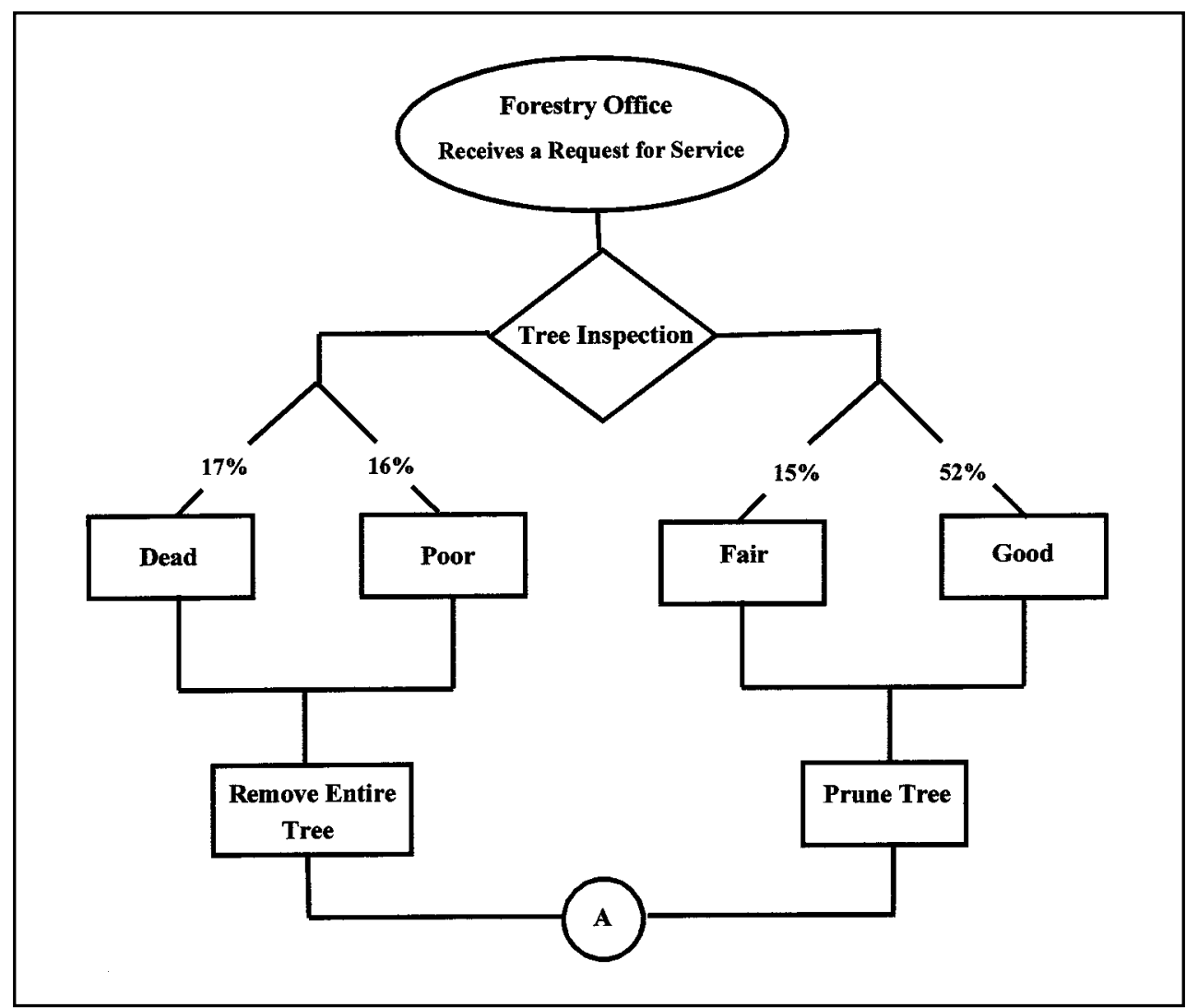

Figure 3. The forestry office is where the simulation begins. Work orders are separated according to tree condition.

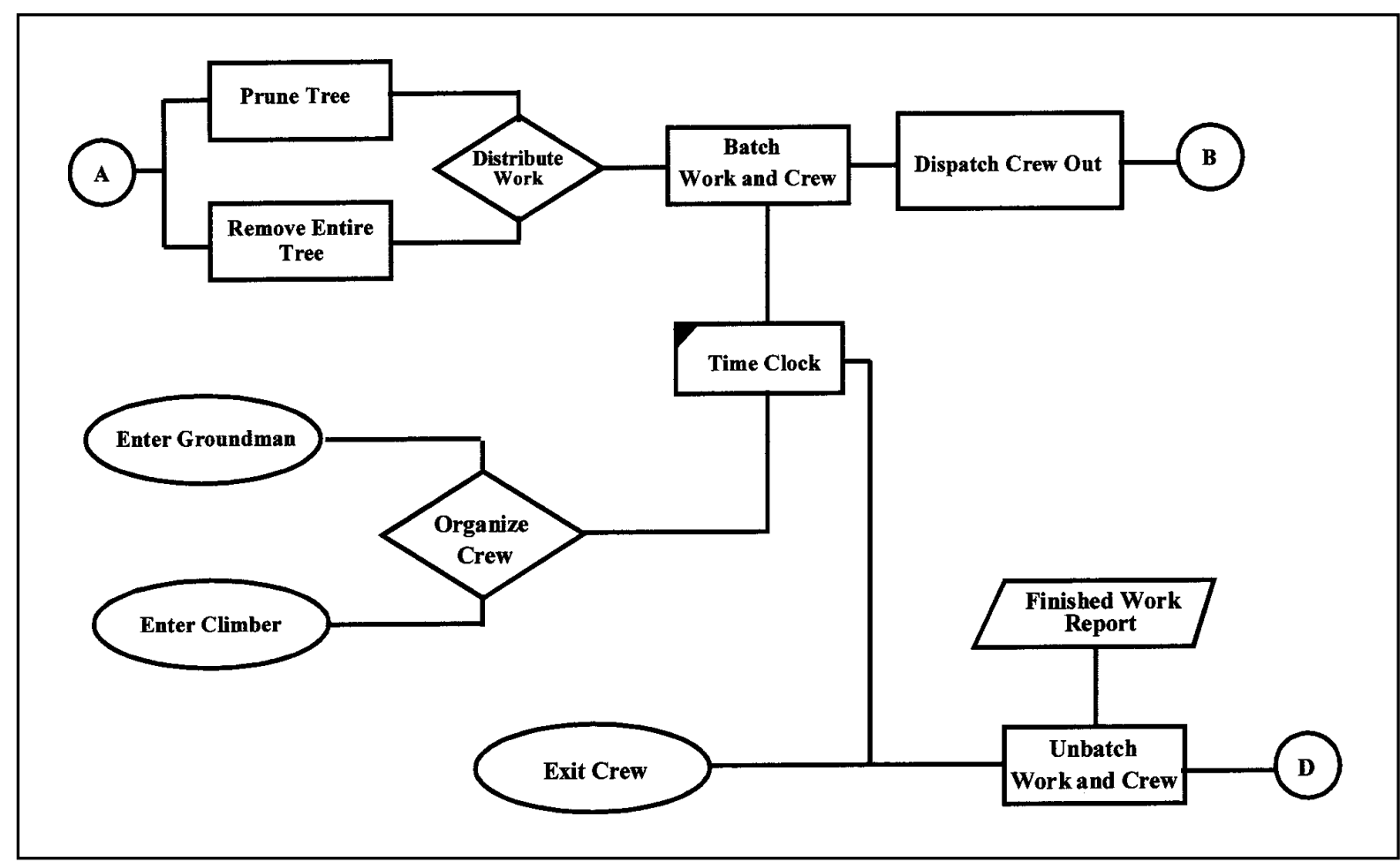

Figure 4. The garage is where work orders are batched with a crew. This is also where the simulation flow ends. 


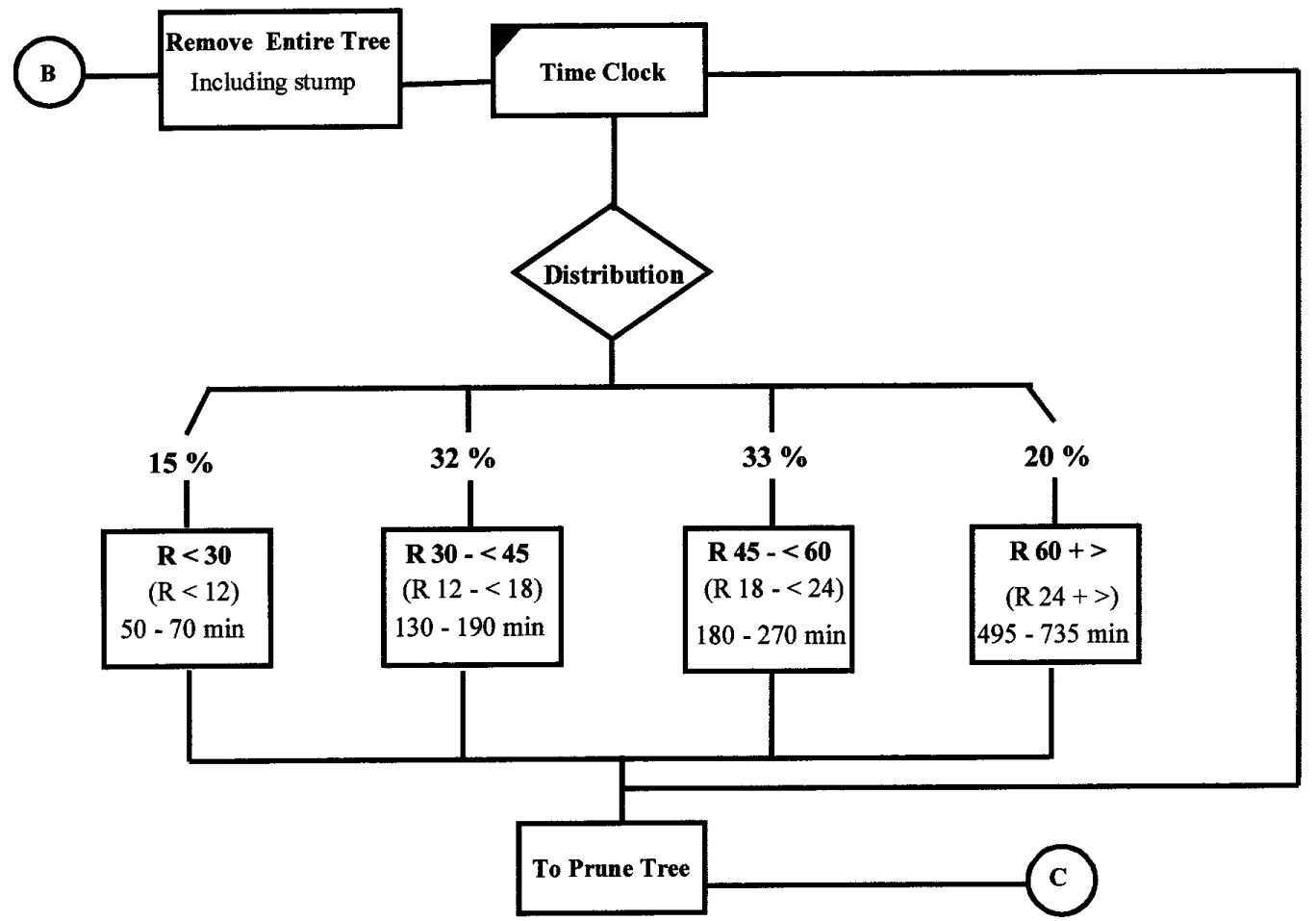

Figure 5. Flow chart for simulated tree removal.

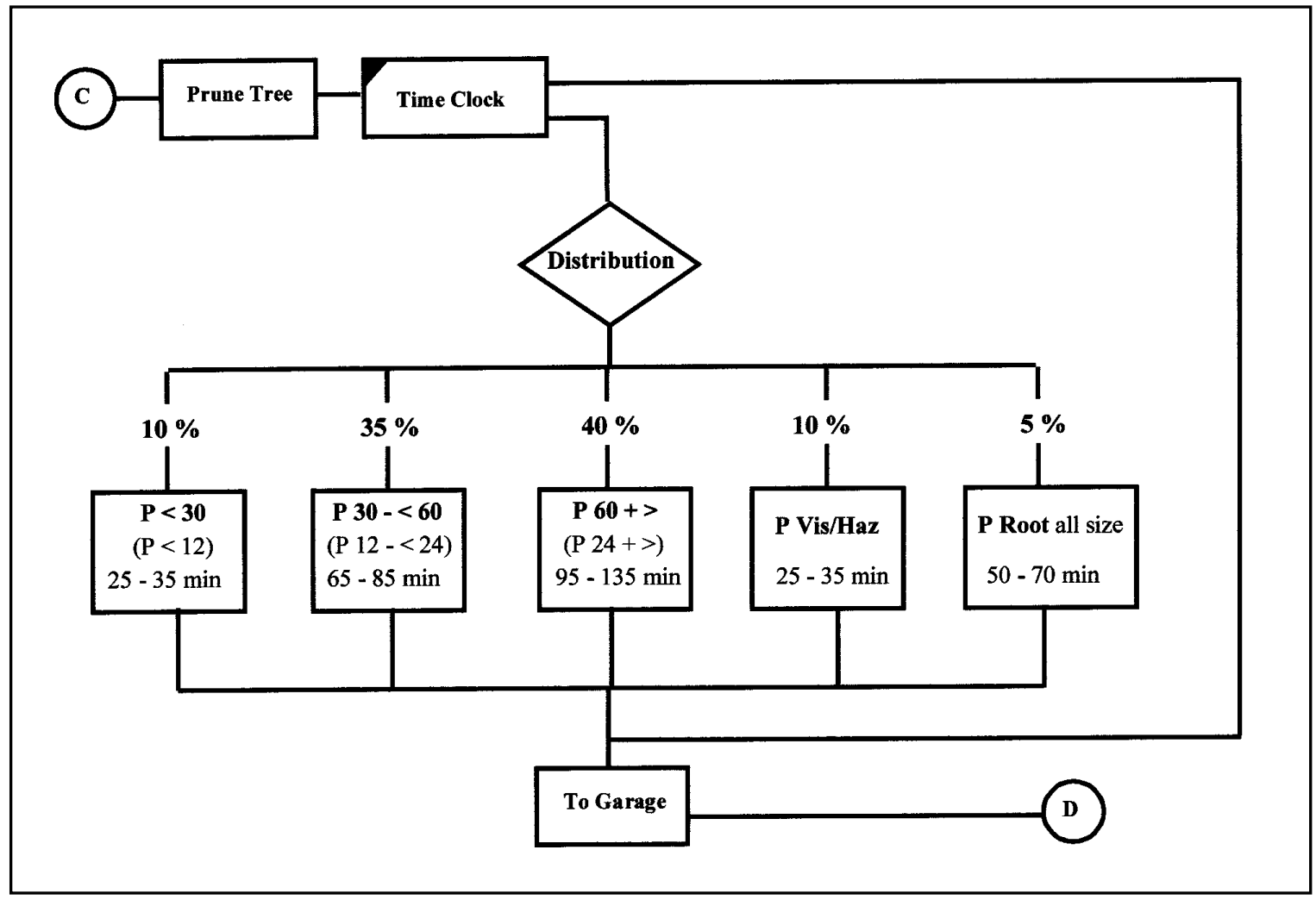

Figure 6. Flow chart for simulated tree pruning. 
adjusted size class information, combined the tree and stump removal operation into a single category, and assigned timing allotments for the work of a two-person crew utilizing all available equipment during a 6-hour productive work day (Figures 5 and 6).

\section{RESULTS AND DISCUSSION}

Several simulation runs were generated in order to identify comparative differences in crew performance given different work assignments. A simulation model "only provides a means for generating representative observations of the measure of performance variable. Thus, it is necessary to repeat the process of using the simulation model to generate samples ..." (Gordon et al. 1990). While system settings for the percentage distributions of work orders and productivity standards for a crew remained constant throughout the comparative runs, changes were made with the number and type of daily work assignments. An example of a typical comparative run would be the daily assignment of one removal and one tree pruning during a simulated 1,250-day period. This allowed the program to calculate the average time and potential backlog for a two-person crew performing the work required to remove 1,250 trees and to prune 1,250 trees. When the assignment changed to a daily workload of one removal and three prunings, the system would calculate 1,250 removals and 3,750 prunings during a simulated 1,250-day run. The 1,250-day time frame was used to ensure computerbased equilibriums worked through the system.

Given the appointed simulation time constraints on work productivity and percentage distributions, limits were reached on the average amount of work that a two-person crew could successfully complete on a daily

\section{Computed backlog}

Removal

Pruning

Average delay time
Removal
Pruning
Crew

Table 1. Simulating 1,250 6-hour tree work days using a two-person crew and equipment at $\$ 500$ per day.

basis. The resulting averages provided a good approximation of possible tree work production. Table 1 shows the results of a simulation run where one removal and three prunings were assigned on a daily basis to a twoperson crew. The data show the number of trees worked on according to size class, the average cost per tree, an accumulated backlog based on incoming work orders, and system delay times. Given the 6-hour production work day, the model computations indicate that a two-person crew handling a FIFO (first in, first out) queue discipline was unable to perform the average daily assignment of one removal and three prunings over the simulated 1,250-day period. The average delay time for the crew was calculated as 1.26 days (Table 1). A calculation in excess of 1.0 indicates that time spent between leaving and returning to the simulated garage exceeded the established 6-hour work allotment.

\section{CONCLUSION}

The software Extend LT allowed for easy model construction, debugging capabilities, and variable changes. The advantage of model simulation is that parameters can easily be changed and results evalu-

\begin{tabular}{|c|c|c|c|}
\hline Remove 1 & \# of trees & $\begin{array}{l}\text { Total cost } \\
\text { at US } \$ 500 / \text { day }\end{array}$ & $\mathrm{US} \$ /$ tree \\
\hline $\mathrm{R}<30$ centimeters & 182 & $\$ 15,349.50$ & $\$ 84.34$ \\
\hline R 30 to 44 centimeters & 406 & $\$ 90,149.00$ & $\$ 222.04$ \\
\hline R 45 to 59 centimeters & 432 & $\$ 135,081.00$ & $\$ 312.69$ \\
\hline $\mathrm{R}>60$ centimeters & 230 & $\$ 199,309.00$ & $\$ 866.56$ \\
\hline Average cost & & & $\$ 371.41$ \\
\hline Work orders completed & 1,250 & & \\
\hline \multicolumn{4}{|l|}{ Prune 3} \\
\hline $\mathrm{P}<30$ centimeters & 378 & $\$ 15,770.80$ & $\$ 41.72$ \\
\hline P 30 to 59 centimeters & 1,324 & $\$ 137,832.00$ & $\$ 104.10$ \\
\hline$P>60$ centimeters & 1,530 & $\$ 244,677.00$ & $\$ 159.92$ \\
\hline $\mathrm{P}$ vis/haz, all sizes & 348 & $\$ 14,547.30$ & $\$ 41.80$ \\
\hline$P$ roots, all sizes & 169 & $\$ 14,101.20$ & $\$ 83.44$ \\
\hline Average cost & & & $\$ 86.20$ \\
\hline Work orders completed & 3,749 & & \\
\hline
\end{tabular}

\begin{tabular}{lll} 
\# of work orders & Average wait (days) & Maximum wait (days) \\
\hline 3,841 & 455.42 & 911 \\
6,641 & 387.39 & 809.75
\end{tabular}

Days

0.74

0.53

1.26 
ated with new variables before making trials in the field. This model of a typical service-on-demand municipal street tree operation may provide decision makers with additional insight into complex "whatif" scenarios. Although, the increased complexities that became apparent during the modeling process could not be performed with the LT version of the software package, additional situations that would allow for more realism, such as enhanced multiple crew scheduling, anticipated sick and vacation days, reshuffling of the work assignments, variable travel delays, and the inevitable equipment breakdowns, could be programmable in a full version of the software.

\section{LITERATURE CITED}

Diamond, B., S. Lamperti, and D. Krahl. 2000. Version 5 User's Guide for Extend, Extend+Manufacturing, Extend+BPR, Extend+Industry, Extend Suite, Industry Suite for Windows or Macintosh (Computer Program). Imagine That, Inc., San Jose, CA.

Gordon, G., I. Pressman, and S. Cohn. 1990. Quantitative Decision Making for Business (3rd ed.). Prentice-Hall, Inc., Englewood Cliffs, NJ. 670 pp.

Law, A.M., and W.D. Kelton. 1991. Simulation Modeling and Analysis (2nd ed.). McGraw-Hill, Inc., New York, NY. 759 pp.

McCabe, J.J. 2001. A summary and forecast of demand for municipal street tree service on Staten Island, NY. J. Arboric. 27(5):277-280.

O’Brien, P.R., K.A. Joehlin, and D.J. O’Brien. 1992. Performance standards for municipal tree maintenance. J. Arboric. 18(6):307-315.

Zillmer, R.E., J.L. Boeder, and K.G. Genich. 2000. A productivity timing system for tree climbing training. J. Arboric. 26(2):97105

\section{Forester II}

NYC Department of Parks \& Recreation

1150 Clove Road

Staten Island, NY 10301, U.S.

jjmccabe@netzero.net
Résumé. En utilisant un logiciel de simulation commercialement disponible, un modèle informatique d'opération typique d'entretien d'arbres de rues municipaux est présenté. Des variables telles que des bons de travail à exécuter, des assignations d'équipes et des normes de productivité, représentatives d'un programme d'entretien d'arbres de rues basé sur des demandes continues de service, ont été incluses. Même si d'autres simulations plus complexes sont impliquées, le modèle qui est développé donne une base par laquelle les décisions de gestion et les opérations typiques d'entretien des arbres peuvent être analysées.

Zusammenfassung. Hier wird ein Computerprogramm vorgestellt, welches mittels Simulations-software typische Straßenbaumpflegeoperationen darstellen kann. Die Variablen, wie z.B. eingehende Arbeitsaufträge, Arbeitsanweisungen und die Produktivitätsstandarts, welche den Arbeitsfluss eines nachfrageorientierten Straßenbaumpflegeprogramms repräsentieren, wurden integriert. Obwohl auch zusätzliche Zusammenhänge miteinbezogen wurden, liefert das entwickelte Modell eine Grundlage, von der Entscheidungsfindungen und typische Baumpflegeoperationen analysiert werden können.

Resumen. Mediante el uso de un software de simulación comercialmente disponible se presenta un modelo para la operación del mantenimiento de árboles urbanos. Se incluyeron variables tales como órdenes de trabajo, equipos de trabajo y estándares de productividad, que representan el flujo del trabajo de un programa de mantenimiento de árboles. Aunque están implicadas ciertas complejidades de simulación, el modelo desarrollado proporciona una base a partir de la cual se puedan tomar decisiones de manejo y puedan ser analizadas las operaciones típicas de cuidado de los árboles. 